\title{
In vitro inhibitory potentials of ethanolic extract of Moringa oleifera flower against enzymes activities linked to diabetes
}

\author{
Olasehinde Oluwaseun Ruth $^{* \mathbb{D}}$, Afolabi Olakunle Bamikole ${ }^{\mathbb{D}}$, Omiyale Benjamin Olusola ${ }^{\mathbb{D}}$, Olaoye Oyindamola \\ Adeniyi $^{\circledR}$ \\ College of Science, Department of Chemical Sciences, Biochemistry Programme, Afe Babalola University, P.M.B 5454 Ado-Ekiti, Ekiti State, Nigeria
}

\section{A R T I C L E IN F O}

Article Type:

Original Article

\section{Article History:}

Received: 14 November 2020

Accepted: 29 April 2021

\section{Keywords:}

Moringa oleifera

Antioxidant activity

a-Amylase

a-Glucosidase

Type II diabetes

\begin{abstract}
A B S T RAC T
Introduction: Diabetes mellitus (DM) has been recognized as the seventh leading cause of global mortality; however, researchers seek alternative means to manage the menace. The current study sought to investigate antioxidant potentials, $\alpha$-amylase and $\alpha$-glucosidase inhibitory activities of ethanolic extract of Moringa oleifera flower in vitro.

Methods: Antioxidant properties of the extract were appraised by assessing its inhibition against 1,1-diphenyl-2-picrylhydrazyl (DPPH), hydroxyl $\left(\mathrm{OH}^{\circ}\right)$ and hydrogen peroxide $\left(\mathrm{H}_{2} \mathrm{O}_{2}\right)$ free radicals, as well as ferric reducing antioxidant power (FRAP), the antidiabetic activity was evaluated by $\alpha$-amylase and $\alpha$-glucosidase inhibition.

Results: In this study, ethanolic extract of $M$. oleifera flower demonstrated a significant $(P<0.05)$ inhibition against DPPH free radical $(43.57-83.56 \%)$ in a concentration-dependent manner, while FRAP $(101.76 \pm 1.63 \mathrm{mg} / 100 \mathrm{~g}), \mathrm{OH} \cdot$ scavenging ability $(71.62 \pm 0.95 \mathrm{mg} / 100 \mathrm{~g})$, and $\mathrm{H}_{2} \mathrm{O}_{2}$ free radical scavenging capacity $(15.33 \pm 1.20 \mathrm{mg} / 100 \mathrm{~g})$ were also observed. In the same manner, ethanolic extract of $M$. oleifera flower revealed a significant $(P<0.05)$ inhibition against $\alpha$-amylase $\left(\mathrm{IC}_{50}=37.63 \mathrm{mg} / \mathrm{mL}\right)$ and $\alpha$-glucosidase activities $\left(\mathrm{IC}_{50}=38.30 \mathrm{mg} / \mathrm{mL}\right)$ in the presence of their respective substrates in a concentration-dependent manner in comparison with acarbose.

Conclusion: Ethanoic extract of M. oleifera flower could be useful as an alternative phytotherapy in the management of DM, having shown a strong antioxidative capacity and substantial inhibition against the activities of key enzymes involved in carbohydrate hydrolysis in vitro.
\end{abstract}

Implication for health policy/practice/research/medical education:

Ethanolic extract of Moringa oleifera flower possesses significant antioxidant and antidiabetic potentials and might be used as an alternative phytotherapy in the management of diabetes mellitus.

Please cite this paper as: Olasehinde OR, Afolabi OB, Omiyale BO, Olaoye OA. In vitro inhibitory potentials of ethanolic extract of Moringa oleifera flower against enzymes activities linked to diabetes. J Herbmed Pharmacol. 2021;10(4):408-414. doi: 10.34172/ jhp.2021.48.

\section{Introduction}

Diabetes mellitus (DM) is a complex multi-systemic disorder characterized by a relative or absolute impaired insulin secretion or its actions leading to disturbances in carbohydrate, protein, and lipid metabolisms (1). This metabolic disorder has been reported to affect approximately $4 \%$ of the global population worldwide with a projection of $5.4 \%$ rise by 2025 (2). However, two major types of DM have been widely recognized, i.e., insulin-dependent (IDDM, type 1) and non-insulindependent diabetes mellitus (NIDDM, type 2). IDDM is an autoimmune disease characterized by a local inflammatory reaction in and around islets followed by selective destruction of insulin-secreting cells, whereas NIDDM is characterized by peripheral insulin resistance and impaired insulin secretion (3).

Several modifications have been reported in DM as a result of changes in body proteins that in turn lead to complications in the eyes (retinopathy), kidneys (nephropathy), nerves (neuropathy), and arteries (atherosclerotic vascular disease) (4). Although, various oral hypoglycemic drugs exist alongside insulin therapy, however, there is no promising therapy to cure DM (5). The conventional management of DM includes reduction 
of demand for insulin, stimulation of endogenous insulin secretion, and inhibition of degradation of oligo- and disaccharides $(5,6)$. Carbohydrate-metabolizing enzymes such as $\alpha$-glucosidases and $\alpha$-amylases have been reported to be responsible for the breakdown of oligo- and/or disaccharides to monosaccharides. However, inhibition of these enzymes has been reported to play a significant role in the management of $\operatorname{NIDDM}(7,8)$. The activities of potential inhibitors of carbohydrate-metabolizing enzymes such as acarbose have been well elucidated and reported (9). Synthetic hypoglycemic agents have been reported for their limitations such as non-specificity, serious side effects (e.g., bloating, abdominal discomfort, diarrhea, and flatulence) (10), and eventual failure in alleviating DM complications (9).

Phytotherapy has recently been reported to play promising roles in the management of DM (9). Moringa oleifera is a tropical and perennial softwood tree with timber of low quality, which for centuries parts of the plant (roots, leaves, stem, and seeds) are edible and have been advocated for nutritional purposes and traditional medicinal and industrial uses (11). Various parts of $M$. oleifera have been reported for their several biological activities. Report shows that its leaves have purgative, antimicrobial, and hypoglycemic properties (12). Its stem bark has been proven to possess anti-cancer, anti-ulcerative, and anti-inflammatory properties (12). Different parts of this plant contain a profile of important minerals and are a good source of protein, vitamins, $\beta$-carotene, amino acids, and various phenolic compounds (13). Hence, this study was designed to appraise the antidiabetic activities of the ethanolic extract of $M$. oleifera flowers through the inhibition of $\alpha$-glucosidase and $\alpha$-amylase enzymatic activities as well as the antioxidant properties.

\section{Materials and methods}

Chemicals used

Ethanol was procured from Merck (Darmstadt, Germany), 1,1-diphenyl-2-picrylhydrazyl (DPPH), acarbose, a-amylase (porcine, EC 3.2.1.1) and a-glucosidase (Saccharomyces cerevisiae; EC 3.2.1.20) were purchased from Sigma Chemical Co. (Sigma-Aldrich, Sternheim, Germany). Butylated hydroxytoluene (BHT) and gallic acid were purchased from Sigma Chemical Co. (St. Louis, MO, USA). All other chemicals and reagents were of analytical grade and prepared in all-glass apparatus.

Sample collection and preparation

Sample collection

M. oleifera flowers were obtained from Ekute quarters, Ado-Ekiti, Ekiti State, Nigeria. A voucher sample was deposited for authentication at the herbarium unit, Department of Plant Biology, University of Ilorin, Kwara State. A voucher number (U.I.H 729) was provided for it from the data base.

\section{Preparation of ethanolic extract of M. oleifera flower}

Fresh flowers of $M$. oleifera were air-dried at room temperature $\left(37^{\circ} \mathrm{C}\right)$ for fourteen (14) days. The dried flowers (50 g) were then pulverized using an automated blender, after which the resulting powder was extracted in $500 \mathrm{~mL} 95 \%$ ethanol for 72 hours at room temperature with a constant agitation. The extract was then filtered using Whatman No. 1 filter paper, and the filtrate was concentrated to dryness in a water bath at $40^{\circ} \mathrm{C}$.

In vitro antioxidant activity assays

Ferric reducing antioxidant power (FRAP) assay

Ferric reducing antioxidant potential of the extract was carried out using the method of Pulido et al (14). Extract $(2.5 \mathrm{~mL})$ was mixed with $2.5 \mathrm{~mL} 200 \mathrm{mM}$ phosphate buffer (pH 6.6) and $2.5 \mathrm{~mL} 1 \%$ potassium ferricyanide. Solution was incubated for 20 minutes at $50^{\circ} \mathrm{C}$ in a water bath and $2.5 \mathrm{~mL} \mathrm{10 \%} \mathrm{trichloroacetic} \mathrm{acid} \mathrm{(TCA)} \mathrm{was} \mathrm{added.} \mathrm{The}$ resulting solution was then centrifuged for 10 minutes at $3000 \mathrm{rpm}$. Then, $5 \mathrm{~mL}$ of the filtrate was mixed with an equal volume of distilled water and $1 \mathrm{~mL} 0.1 \% \mathrm{FeCl}_{3}$. The mixture was read at $700 \mathrm{~nm}$, and gallic acid was used as standard.

DPPH free radical scavenging activity

DPPH free radical scavenging ability of the extract was carried out by Gyamfi et al (15). Diluted extract ( $1 \mathrm{~mL}$ ) was mixed with $1 \mathrm{~mL} 0.4 \mathrm{mM} \mathrm{DPPH}$ solution in methanol. The mixture was incubated in the dark for 30 minutes and was read at $516 \mathrm{~nm}$. DPPH radical scavenging assay was expressed as percentage (\%) control inhibition. Butylated hydroxytoluene (BHT) was used as a standard.

$$
\text { DPPH inhibition }(\%)=\frac{\mathrm{A}_{540} \text { control- } \mathrm{A}_{540} \text { sample } \times 100}{\mathrm{~A}_{540} \text { control }}
$$

$\left(\mathrm{A}_{405}\right.$ control, the absorbance of the test without extract; $\mathrm{A}_{405}$ sample, the absorbance of the test in the presence of extract)

\section{Hydroxyl radical $(\mathrm{OH})$ scavenging activity}

Hydroxyl radical scavenging ability of the extract was measured according to the method of Klein et al (16). The extract $(0.2 \mathrm{~mL})$ was mixed with $1 \mathrm{~mL}$ iron- EDTA solution $(0.13 \%$ ferrous ammonium sulfate in $0.26 \%$ EDTA), $0.5 \mathrm{~mL} 0.018 \%$ EDTA and $1 \mathrm{~mL}$ DMSO solution ( $0.85 \%$ in $0.1 \mathrm{~mol} / \mathrm{L}$ phosphate buffered saline $\mathrm{pH} 7.4)$. The reaction was terminated by the addition of $1 \mathrm{~mL}$ trichloroacetic acid. Then, $3 \mathrm{~mL}$ Nash reagent $(7.5 \mathrm{~g}$ ammonium acetate, $0.3 \mathrm{~mL}$ glacial acetic acid, $0.2 \mathrm{~mL}$ acetylacetone, and distilled water-100 mL) was added to the above mixture and incubated at room temperature for 15 minutes. The mixture was read at $412 \mathrm{~nm}$ with a UV-visible spectrophotometer. The hydroxyl radical scavenging ability was expressed as $\mathrm{mg} / 100 \mathrm{~g}$ of dried 
sample using gallic acid as standard.

Hydrogen peroxide $\left(\mathrm{H}_{2} \mathrm{O}_{2}\right)$ radical scavenging ability The ability of the extract to scavenge hydrogen peroxide was determined according to the protocol of Ruch et al (17). Hydrogen peroxide (40mM) was prepared in phosphate buffer ( $\mathrm{pH}$ 7.4). The extract, dissolved in distilled water, was mixed with hydrogen peroxide solution $(0.6 \mathrm{~mL}, 40 \mathrm{mM})$. Hydrogen peroxide absorbance was determined 10 minutes later against a solution containing the phosphate buffer without $\mathrm{H}_{2} \mathrm{O}_{2}$, and read at $230 \mathrm{~nm}$. The hydrogen peroxide radical scavenging ability was expressed as $\mathrm{mg} / 100 \mathrm{~g}$ of the dried sample using gallic acid as standard.

In vitro carbohydrate-hydrolyzing enzymes inhibitory activity assays

$\alpha$-Glucosidase (EC 3.2.1.20) inhibitory assay

The $\alpha$-glucosidase inhibitory activity was determined according to the method described by Ademiluyi and Oboh (18), with slight modifications. Briefly, $250 \mu \mathrm{L}$ of the extract at different concentrations $(1-5 \mathrm{mg} / \mathrm{mL})$ was incubated with $500 \mu \mathrm{L} \alpha$-glucosidase $(1.0 \mathrm{U} / \mathrm{mL})$ solution in $100 \mathrm{mmol} / \mathrm{L}$ phosphate buffer $(\mathrm{pH} 6.8)$ at $37^{\circ} \mathrm{C}$ for 15 minutes. Thereafter, $250 \mu \mathrm{L} \mathrm{pNPG}$ solution $(5 \mathrm{mmol} / \mathrm{L})$ in $100 \mathrm{mmol} / \mathrm{L}$ phosphate buffer ( $\mathrm{pH}$ 6.8) was added, and the mixture was further incubated at $37^{\circ} \mathrm{C}$ for 20 minutes. The absorbance of the released $p$-nitrophenol was measured at $405 \mathrm{~nm}$, and the activity was expressed as percentage (\%) control inhibition.

$\alpha$-glucosidase inhibition $(\%)=\frac{\mathrm{A}_{405} \text { control- } \mathrm{A}_{405} \text { sample } \times 100}{\mathrm{~A}_{405} \text { control }}$ $\left(\mathrm{A}_{405}\right.$ control $=$ absorbance of the test without extract; $\mathrm{A}_{405}$ sample $=$ absorbance of the test in the presence of extract).

\section{$\alpha$-Amylase (EC 3.2.1.1) inhibitory assay}

The $\alpha$-amylase inhibitory activity was determined according to the method described by Shai et al (19), with slight modifications. A volume of $250 \mu \mathrm{L}$ of the extract at different concentrations (1-5 mg $/ \mathrm{mL}$ ) was incubated with $500 \mu \mathrm{L}$ porcine pancreatic amylase $(2 \mathrm{U} / \mathrm{mL})$ in 100 $\mathrm{mmol} / \mathrm{L}$ phosphate buffer ( $\mathrm{pH} 6.8$ ) at $37^{\circ} \mathrm{C}$ for 20 minutes. $250 \mu \mathrm{L}$ of $1 \%$ starch dissolved in $100 \mathrm{mmol} / \mathrm{L}$ phosphate buffer ( $\mathrm{pH}$ 6.8) was then added to the reaction mixture and incubated at $37^{\circ} \mathrm{C}$ for 1 hour. One milliliter of DNSA color reagent was then added and boiled for 10 minutes. The absorbance of the resulting mixture was measured at $540 \mathrm{~nm}$ and the inhibitory activity was expressed as percentage (\%) control inhibition.

$\alpha$-Amylase inhibition $(\%)=\frac{\mathrm{A}_{540} \text { control- } \mathrm{A}_{540} \text { sample } \times 100}{\mathrm{~A}_{540} \text { control }}$

( $\mathrm{A}_{405}$ control, absorbance of the test without extract;
$\mathrm{A}_{405}$ sample, absorbance of the test in the presence of extract).

Determination of $\mathrm{IC}_{50}$

The concentration of extract required to cause $50 \%$ inhibition $\left(\mathrm{IC}_{50}\right)$ was calculated by linear regression curve derived from graph of various percentage (\%) inhibitions against different concentrations of the extract used.

Data analyses

Data were analyzed using one-way analysis of variance (ANOVA) followed by the Duncan multiple range test and graphical representation of results by GraphPad Prism 5 program (GraphPad Software, San Diego, CA, USA). Statistical significance was considered at $P$ value $<0.05$, with results expressed as mean $\pm S D(n=3)$.

\section{Results}

In vitro antioxidant properties of ethanolic extract of $\mathrm{M}$. oleifera flower

As shown in Figure 1, the extract revealed a significant $(P<0.05)$ inhibitory activity against DPPH in a concentration-dependent manner. However, ethanolic extract of $M$. oleifera flower at different concentrations $(10-50 \mathrm{mg} / \mathrm{mL})$ exhibited strong inhibition against $\mathrm{DPPH}$ in a dose-dependent manner $\left(\mathrm{IC}_{50}=15.89 \mathrm{mg} / \mathrm{mL}\right.$ ) (Table 1 ), while $\mathrm{BHT}$ at the same concentration had $\mathrm{IC}_{50}=5.47$

Figure 2 shows the reductive capacities of ethanolic extract of $M$. oleifera flower and gallic acid against ferric, $\mathrm{OH}$ radical activity, and hydrogen peroxide inhibition. Ethanolic extract of $M$. oleifera flower showed a very high ferric reducing power $(101.76 \mathrm{mg} / \mathrm{mL})$ and moderately high $\mathrm{OH}$ free radical scavenging $(71.62 \mathrm{mg} / \mathrm{mL})$ and hydrogen peroxide $(15.33 \mathrm{mg} / \mathrm{mL})$ inhibitory activities. However, gallic acid showed relatively higher ferric reducing power (118.91 \pm 1.15$), \mathrm{OH}$ free radical scavenging $(92.21 \pm 1.01)$, and hydrogen peroxide $(20.11 \pm 0.98 \mathrm{mg} /$ $\mathrm{mL}$ ) inhibitory activities.

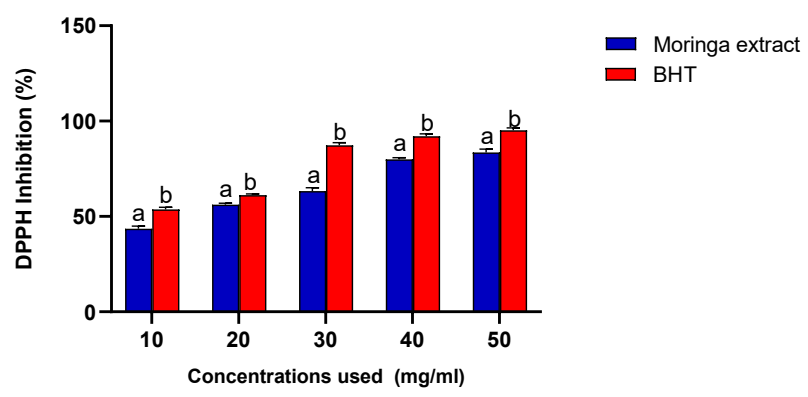

Figure 1. DPPH (1,1-diphenyl-2-picrylhydrazyl) free radical scavenging ability of ethanolic extract of $M$. oleifera flowers. Results are represented as mean of triplicate determinations $\pm S D(n=3)$. In each concentration, different alphabets ( $a$ and $b$ ) on bars represent statistically significant $(P<0.05)$ difference. Note: BHT: Butylated hydroxytoluene. 
Table 1. $I C_{50}$ values of the ethanolic extract of $M$. oleifera flower on $\alpha$-amylase, $\alpha$-glucosidase and DPPH

\begin{tabular}{lccc}
\hline & $\begin{array}{c}\alpha-A m y l a s e \\
(\mathrm{mg} / \mathrm{mL})\end{array}$ & $\begin{array}{c}\alpha-G l u c o s i d a s e \\
(\mathbf{m g} / \mathbf{m L})\end{array}$ & $\begin{array}{c}\mathrm{DPPH} \\
(\mathrm{mg} / \mathrm{mL})\end{array}$ \\
\hline Ethanolic extract of MOF & 37.33 & 38.30 & 15.89 \\
Acarbose & 13.63 & 23.94 & - \\
Gallic acid & - & - & 5.47
\end{tabular}

Results are represented as mean of triplicate determinations $\pm S D(n=3)$. MOF: M. oleifera flower; DPPH: 1,1-diphenyl-2-picrylhydrazyl.

In vitro enzyme inhibitory activity

As shown in Figure 3, the extract revealed a significant $(P<0.05) \quad$ inhibitory activity against $\alpha$-glucosidase enzyme in a concentration-dependent manner. However, the percentage inhibition varied from $43.21 \pm 0.21$ to $88.20 \pm 0.99 \%$ from the lowest to the highest concentration $\left(\mathrm{IC}_{50}=38.30 \mathrm{mg} / \mathrm{mL}\right)$ (Table 1). Thus, acarbose at the concentrations of $20-100 \mathrm{mg} / \mathrm{mL}$ showed $\alpha$-glucosidase inhibitory activity from $51.60 \pm 0.46$ to $93.10 \pm 1.11 \%$ $\left(\mathrm{IC}_{50}=23.94 \mathrm{mg} / \mathrm{mL}\right)$.

As shown in Figure 4, the extract revealed a significant $(P<0.05)$ inhibitory activity against $\alpha$-amylase enzyme in a concentration-dependent manner. However, ethanolic extract of M. oleifera at different concentrations (20-100 $\mathrm{mg} / \mathrm{mL}$ ) exhibited strong inhibition against $\alpha$-amylase inhibitory activity in a dose-dependent manner $\left(\mathrm{IC}_{50}=\right.$ $37.63 \mathrm{mg} / \mathrm{mL}$ ) (Table 1). Acarbose at the concentrations of $20-100 \mathrm{mg} / \mathrm{mL}$ showed $\alpha$-amylase inhibitory activity from $56.61 \pm 1.18 \%$ to $95.20 \pm 1.57 \%$ with $\mathrm{IC}_{50}=13.63 \mathrm{mg} / \mathrm{mL}$.

\section{Discussion}

Polyphenolic compounds have been implicated as a possible bioactive antidiabetic agents (20). In living systems, free radicals are constantly generated and can cause extensive damage to tissues and biomolecules, leading to various disease conditions, especially metabolic disorders (21). The use of DPPH to estimate the activity of antioxidants has recently been reviewed (22). Recent studies have implicated the consumption of natural antioxidants from food as an alternative in the control of free radical activities $(23,24)$. In the present study (Figure 1), the antioxidant capacity of ethanolic extract of dried flower of M. oleifera was measured via DPPH inhibition and there was a promising concentration-dependent inhibitory ability of free radicals by ethanolic extract of dried flower of M. oleifera.

Hydroxyl radicals are the major active oxygen species causing lipid peroxidation and enormous biological damages (25). However, as demonstrated in this study (Figure 2), incubation of ferric-EDTA with ascorbic acid and $\mathrm{H}_{2} \mathrm{O}_{2}$ at $\mathrm{pH}$ 7.4, in the presence of 2-deoxyribose generated an MDA-like product with resultant pink chromogen upon heating with TBA (26), which was sufficiently inhibited at the introduction of ethanolic extract of dried flowers of M. oleifera. Similarly, inhibition

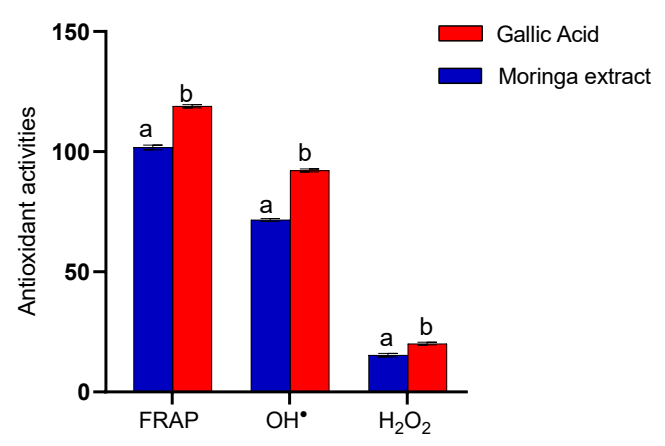

Figure 2. Ferric reducing antioxidant power (FRAP; $100 \mathrm{mg} / \mathrm{g}$ dried sample), hydroxyl radical $(\mathrm{OH} \bullet ; 100 \mathrm{mg} / \mathrm{g}$ dried sample) scavenging activity and hydrogen peroxide $\left(\mathrm{H}_{2} \mathrm{O}_{2} ; 100 \mathrm{mg} / \mathrm{g}\right.$ dried sample $)$ scavenging ability of ethanolic extract of $\mathrm{M}$. oleifera flower. In each concentration, different alphabets $(a \& b)$ on bars represent statistically significant $(P<0.05)$ difference.

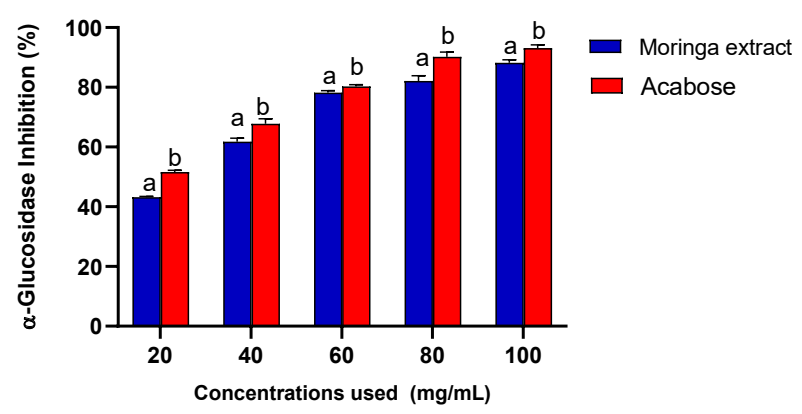

Figure 3. a-Glucosidase inhibitory activity of ethanolic extract of M. oleifera flower. Results are represented as mean of triplicate determinations $\pm S D(n=3)$. In each concentration, different alphabets (a\&b) on bars represent statistically significant $(P<0.05)$ difference.

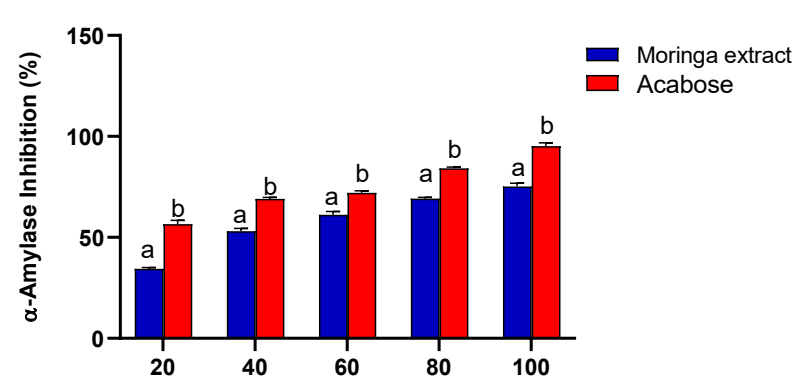

Figure 4. $\alpha$-Amylase inhibitory activity of ethanolic extract of $M$. oleifera flower. Results are represented as mean of triplicate determinations $\pm \mathrm{SD}(\mathrm{n}=3)$. In each concentration, different alphabets (a\&b) on bars represent statistically significant $(P<0.05)$ difference.

of hydrogen peroxide $\left(\mathrm{H}_{2} \mathrm{O}_{2}\right)$ generating species has been emphasized in recent studies, due to its ability to penetrate biological membranes and produce hydroxyl radical (27). Thus, removing it is paramount in the protection of the biological system (28). Moreover, ROS can react with most biomolecules such as protein, lipids, 
and DNA thereby causing oxidative damage, which also plays a significant pathological role in human diseases $(29,30)$. Antioxidants can counteract the oxidation process via various mechanisms, including reacting with free radicals, chelating catalytic metals, oxygen scavenging, decomposition of peroxides, and preventing chain initiation (27,31-33). As shown in this study (Figure 2), ethanolic extract of the dried flower of $M$. oleifera demonstrated an inhibitory potential similar to that of a known standard. As revealed in this study, $\mathrm{H}_{2} \mathrm{O}_{2}-$ scavenging ability of ethanolic extract of the flower of $M$. oleifera may be attributed to the presence of polyphenolic groups as recently reported by Arise et al (34), through donating electrons to $\mathrm{H}_{2} \mathrm{O}_{2}$, thereby neutralizing it into water.

Furthermore, the reducing capacity of a compound may serve as a significant indicator of its potential antioxidant activity (35). More so, the activities of antioxidants have been attributed to various mechanisms such as prevention of chain initiation, decomposition of peroxides, reducing capacity, and radical scavenging ability (31). With the results observed in this study, the reducing power of ethanolic extract of dried flower of M. oleifera was lower compared to the standard. However, this result indicates that ethanolic extract of dried flower of $M$. oleifera contains significant amounts of flavonoids and phenolic compounds (34). These compounds have been reported to show good antioxidant potential on human nutrition and health considerably (36). Phenolic compounds are very important plant constituents due to their hydroxyl group's confer-scavenging ability (37).

In the management of DM, inhibition of key enzymes involved in the breakdown of carbohydrate ( $\alpha$-amylase and $a$-glucosidase) leads to inhibition of starch hydrolysis resulting into a decrease in glucose available for assimilation into the blood (regulating postprandial glycemic level) (38). Several in vitro studies have confirmed the inhibitory potential of medicinal plants on $\alpha$-amylase and a-glucosidase activities; whereas, in some cases, the bioactive compounds responsible for this mechanism of action have been identified (39-41). In this study (Figures 3 and 4), the ethanolic extract of $M$. oleifera flower showed a reliable inhibitory effect on $\alpha$-glucosidase and $\alpha$-amylase enzymatic activities in a concentration-dependent trend. This observation was as well compared favorably with a known synthetic inhibitor. The inhibition of $\alpha$-amylase and $\alpha$-glycosidase enzymes by ethanolic extract of dried flower of $M$. oleifera in the present study provides a strong biochemical basis for its use in the management of DM.

\section{Conclusion}

This study has revealed various biological activities of ethanolic extract of $M$. oleifera flower. Ethanolic extract of M. oleifera flower demonstrated a promising therapeutic potentiality through free radical scavenging ability and inhibitory activities on $\alpha$-amylase and a-glucosidase which could be considered as an alternative phytotherapy in the mangement of NIDDM. Therefore, isolation, purification, and characterization of compounds responsible for these acclaimed activities of $M$. oleifera flower are suggested for further studies.

\section{Acknowledgment}

The authors hereby appreciate the staff of Biochemistry Unit, Afe Babalola University for their support during this study.

\section{Authors' contributions}

OOR conceptualized the research and prepared the draft of manuscript; $\mathrm{AOB}$ reviewed the literature, analyzed the data, and prepared the draft; OBO conducted the research and analyzed the data; OOA conducted the research and analyzed the data. All authors read and approved the final report.

\section{Conflict of interest}

No conflict of interest was declared by the authors.

\section{Ethical considerations}

Ethics approval was obtained from the Afe Babalola University ethical committee (Ethical code: ABUAD/ ACA/458).

\section{Funding/Support}

No financial support was received from governmental/ NGO body

\section{References}

1. Kumar GP, Arulselvan P, Durairaj SK, Subramanian SP. Anti-diabetic activity of fruits of Terminalia chebula on streptozotocin induced diabetic rats. J Health Sci. 2006;52(3):283-91. doi: 10.1248/jhs.52.283.

2. Kim SH, Hyun SH, Choung SY. Anti-diabetic effect of cinnamon extract on blood glucose in $\mathrm{db} / \mathrm{db}$ mice. J Ethnopharmacol. 2006;104(1-2):119-23. doi: 10.1016/j. jep.2005.08.059.

3. Barik R, Jain S, Qwatra D, Joshi A, Tripathi GS, Goyal R. Antidiabetic activity of aqueous root extract of Ichnocarpus frutescens in streptozotocin-nicotinamide induced type-II diabetes in rats. Indian J Pharmacol. 2008;40(1):19-22. doi: 10.4103/0253-7613.40484.

4. Bailes BK. Diabetes mellitus and its chronic complications. AORN J. 2002;76(2):265-82. doi: 10.1016/s00012092(06)61065-x.

5. Perfetti R, Barnett PS, Mathur R, Egan JM. Novel therapeutic strategies for the treatment of type 2 diabetes. Diabetes Metab Rev. 1998;14(3):207-25. doi: 10.1002/(sici)10990895(1998090)14:3<207::aid-dmr214>3.0.co;2-j.

6. Groop L, Forsblom C, Lehtovirta M. Characterization of the prediabetic state. Am J Hypertens. 1997;10(9 Pt 2):172S-80S. doi: 10.1016/s0895-7061(97)00149-0.

7. Alexander RJ. Maltodextrins: production, properties 
and applications. In: Schenk FW, Hebeda RE, eds. Starch Hydrolysis Products: Worldwide Technology, Production and Applications. New York: VCH Publishers; 1999. p. 62122.

8. Dineshkumar B, Mitra A, Manjunatha M. A comparative study of alpha amylase inhibitory activities of common anti-diabetic plants at Kharagpur 1 block. Int J Green Pharm. 2010;4(2):115-21. doi: 10.4103/0973-8258.63887.

9. Afolabi OB, Oloyede OI, Agunbiade SO. Inhibitory potentials of phenolic-rich extracts from Bridelia ferruginea on two key carbohydrate-metabolizing enzymes and $\mathrm{Fe}(2+)$-induced pancreatic oxidative stress. J Integr Med. 2018;16(3):192-8. doi: 10.1016/j.joim.2018.04.006.

10. Cheng AY, Fantus IG. Oral antihyperglycemic therapy for type 2 diabetes mellitus. CMAJ. 2005;172(2):213-26. doi: 10.1503/cmaj.1031414.

11. Leone A, Spada A, Battezzati A, Schiraldi A, Aristil J, Bertoli S. Moringa oleifera seeds and oil: characteristics and uses for human health. Int J Mol Sci. 2016;17(12). doi: 10.3390/ ijms17122141.

12. Siddhuraju P, Becker K. Antioxidant properties of various solvent extracts of total phenolic constituents from three different agroclimatic origins of drumstick tree (Moringa oleifera Lam.) leaves. J Agric Food Chem. 2003;51(8):214455. doi: 10.1021/jf020444+.

13. Anwar F, Latif S, Ashraf M, Gilani AH. Moringa oleifera: a food plant with multiple medicinal uses. Phytother Res. 2007;21(1):17-25. doi: 10.1002/ptr.2023.

14. Pulido R, Bravo L, Saura-Calixto F. Antioxidant activity of dietary polyphenols as determined by a modified ferric reducing/antioxidant power assay. J Agric Food Chem. 2000;48(8):3396-402. doi: 10.1021/jf9913458.

15. Gyamfi MA, Yonamine M, Aniya Y. Free-radical scavenging action of medicinal herbs from Ghana: Thonningia sanguinea on experimentally-induced liver injuries. Gen Pharmacol. 1999;32(6):661-7. doi: 10.1016/s03063623(98)00238-9.

16. Klein SM, Cohen G, Cederbaum AI. Production of formaldehyde during metabolism of dimethyl sulfoxide by hydroxyl radical generating systems. Biochemistry. 1981;20(21):6006-12. doi: 10.1021/bi00524a013.

17. Kelm MA, Nair MG, Strasburg GM, DeWitt DL. Antioxidant and cyclooxygenase inhibitory phenolic compounds from Ocimum sanctum Linn. Phytomedicine. 2000;7(1):7-13. doi: 10.1016/s0944-7113(00)80015-x.

18. Ademiluyi AO, Oboh G. Soybean phenolic-rich extracts inhibit key-enzymes linked to type 2 diabetes ( $\alpha$-amylase and a-glucosidase) and hypertension (angiotensin I converting enzyme) in vitro. Exp Toxicol Pathol. 2013;65(3):305-9. doi: 10.1016/j.etp.2011.09.005.

19. Shai LJ, Masoko P, Mokgotho MP, Magano SR, Mogale AM, Boaduo N, et al. Yeast alpha glucosidase inhibitory and antioxidant activities of six medicinal plants collected in Phalaborwa, South Africa. S Afr J Bot. 2010;76(3):465-70. doi: 10.1016/j.sajb.2010.03.002.

20. Coman C, Rugina OD, Socaciu C. Plants and natural compounds with antidiabetic action. Not Bot Horti Agrobot Cluj-Napoca. 2012;40(1):314-25. doi: 10.15835/ nbha4017205.

21. Halliwell B, Gutteridge JM. Free Radicals in Biology and
Medicine. New York: Oxford University Press; 1999. p. 105245.

22. Molyneux P. The use of the stable free radical diphenylpicrylhydrazyl (DPPH) for estimating antioxidant activity. Songklanakarin J Sci Technol. 2004;26(2):211-9.

23. Yazdanparast $\mathrm{R}$, Ardestani $A$. In vitro antioxidant and free radical scavenging activity of Cyperus rotundus. J Med Food. 2007;10(4):667-74. doi: 10.1089/jmf.2006.090.

24. Yazdanparast R, Bahramikia S, Ardestani A. Nasturtium officinale reduces oxidative stress and enhances antioxidant capacity in hypercholesterolaemic rats. Chem Biol Interact. 2008;172(3):176-84. doi: 10.1016/j.cbi.2008.01.006.

25. Aurand LW, Boone NH, Giddings GG. Superoxide and singlet oxygen in milk lipid peroxidation. J Dairy Sci. 1977;60(3):363-9. doi: 10.3168/jds.s0022-0302(77)83874-5.

26. Halliwell B, Gutteridge JM, Aruoma OI. The deoxyribose method: a simple "test-tube" assay for determination of rate constants for reactions of hydroxyl radicals. Anal Biochem. 1987;165(1):215-9. doi: 10.1016/0003-2697(87)90222-3.

27. Wang SY, Jiao H. Scavenging capacity of berry crops on superoxide radicals, hydrogen peroxide, hydroxyl radicals, and singlet oxygen. J Agric Food Chem. 2000;48(11):567784. doi: $10.1021 /$ jf000766i.

28. Gülçin I, Alici HA, Cesur M. Determination of in vitro antioxidant and radical scavenging activities of propofol. Chem Pharm Bull (Tokyo). 2005;53(3):281-5. doi: 10.1248/ cpb.53.281.

29. Nordberg J, Arnér ES. Reactive oxygen species, antioxidants, and the mammalian thioredoxin system. Free Radic Biol Med. 2001;31(11):1287-312. doi: 10.1016/s08915849(01)00724-9.

30. Gülçin I, Buyukokuroglu ME, Oktay M, Kufrevioglu OI. On the in vitro antioxidative properties of melatonin. J Pineal Res. 2002;33(3):167-71. doi: 10.1034/j.1600079x.2002.20920.

31. Yildirim A, Mavi A, Oktay M, Kara AA, Algur OF, Bilaloglu V. Comparison of antioxidant and antimicrobial activities of Tilia (Tilia argentea Desf ex DC), sage (Salvia triloba L.), and black tea (Camellia sinensis) extracts. J Agric Food Chem. 2000;48(10):5030-4. doi: 10.1021/jf000590k.

32. Büyükokuroğlu ME, GülçIn I, Oktay $M$, Küfrevioğlu OI. In vitro antioxidant properties of dantrolene sodium. Pharmacol Res. 2001;44(6):491-4. doi: 10.1006/ phrs.2001.0890.

33. Oloyede FM, Oloyede FA. The antioxidant and food value of Chrysophyllum albidium G. Don. Scholars J Agric Vet Sci. 2014;1(1):1-5.

34. Arise RO, Aburo OR, Farohunbi ST, Adewale AA. Antidiabetic and antioxidant activities of ethanolic extract of dried flowers of Moringa oleifera in streptozotocin-induced diabetic rats. Acta Fac Med Naiss. 2016;22;33(4):259-72. doi: 10.1515/afmnai-2016-0028.

35. Ogbunugafor HA, Eneh FU, Ozumba AN, Igwo-Ezikpe MN, Okpuzor J, Igwilo IO, et al. Physico-chemical and antioxidant properties of Moringa oleifera seed oil. Pak J Nut. 2011;10(5):409-14.

36. Cartea ME, Francisco M, Soengas P, Velasco P. Phenolic compounds in Brassica vegetables. Molecules. 2010;16(1):251-80. doi: 10.3390/molecules16010251.

37. Cook NC, Samman S. Flavonoids-chemistry, metabolism, 
cardioprotective effects, and dietary sources. J Nutr Biochem. 1996;7(2):66-76.doi:10.1016/s0955-2863(95)00168-9.

38. Mahmood N. A review of $\alpha$-amylase inhibitors on weight loss and glycemic control in pathological state such as obesity and diabetes. Comp Clin Path. 2016;25(6):1253-64. doi: 10.1007/s00580-014-1967-x.

39. Khan S, Nazir M, Raiz N, Saleem M, Zengin G, Fazal G, et al. Phytochemical profiling, in vitro biological properties and in silico studies on Caragana ambigua stocks (Fabaceae): a comprehensive approach. Ind Crops Prod. 2019;131:11724. doi: 10.1016/j.indcrop.2019.01.044.

40. Jia W, Gao W, Tang L. Antidiabetic herbal drugs officially approved in China. Phytother Res. 2003;17(10):1127-34. doi: $10.1002 /$ ptr.1398.

41. Manikandan R, Anand AV, Muthumani GD. Phytochemical and in vitro anti-diabetic activity of methanolic extract of Psidium guajava leaves. Int J Curr Microbiol Appl Sci. 2013;2(2):15-9. 